\title{
The Deposit Formation Mechanism in Coal-Fired Rotary Kiln for Iron Ore Pellet Production: A Review
}

\author{
Shuai Wang (D), Yufeng Guo *, Kuo Liu *, Zhuang Yang, Yajing Liu, Ying Jiang, Feng Chen, Fuqiang Zheng \\ and Lingzhi Yang
}

check for updates

Citation: Wang, S.; Guo, Y.; Liu, K.; Yang, Z.; Liu, Y.; Jiang, Y.; Chen, F.; Zheng, F.; Yang, L. The Deposit Formation Mechanism in Coal-Fired Rotary Kiln for Iron Ore Pellet Production: A Review. Crystals 2021, 11,974. https://doi.org/10.3390/ cryst11080974

Academic Editors: Daniel Errandonea and Pavel Lukáč

Received: 16 July 2021

Accepted: 15 August 2021

Published: 17 August 2021

Publisher's Note: MDPI stays neutral with regard to jurisdictional claims in published maps and institutional affiliations.

Copyright: (c) 2021 by the authors. Licensee MDPI, Basel, Switzerland. This article is an open access article distributed under the terms and conditions of the Creative Commons Attribution (CC BY) license (https:/ / creativecommons.org/licenses/by/ $4.0 /)$
School of Minerals Processing and Bioengineering, Central South University, Changsha 410083, China; wang_shuai@csu.edu.cn (S.W.); 205611068@csu.edu.cn (Z.Y.); 195611027@csu.edu.cn (Y.L.); JYing007@csu.edu.cn (Y.J.); csuchenf@csu.edu.cn (F.C.); csf.q.zheng@csu.edu.cn (F.Z.); yanglingzhi@csu.edu.cn (L.Y.)

* Correspondence: yfguo@csu.edu.cn (Y.G.); liukuo@csu.edu.cn (K.L.); Tel.: +86-0731-88830346 (Y.G. \& K.L.)

\begin{abstract}
The deposit-forming problem is one of the main bottlenecks restricting the yield and production benefit of iron ore pellets produced by coal-fired rotary kilns. In order to implement measures to ensure the efficient production of pellets by coal-fired rotary kilns, the mechanism and influencing factors on the deposit formation were reviewed. The pellet powder and coal ash come together to form the material base of the deposit. Meanwhile, the local reducing atmosphere caused by the continued combustion of residual carbon increases the $\mathrm{FeO}$ content, resulting in the formation of low-melting-point silicates. Moreover, alkali metal elements in coal ash can also promote liquid phase formation to cause serious deposit aggregation problems. During high-temperature roasting, the liquid phase corrodes the surface of the refractory brick to form the initial deposit, whereafter, it binds the pellet powder and coal ash from the material layer, which causes the deposit to accumulate continuously. The deposit formation of coal-fired rotary kilns is the result of interaction between many factors, which includes the quality of the green pellets, the composition of coal ash, the combustion efficiency of pulverized coal, roasting temperature, FeO content and alkali metal input. Finally, it is recommended that some measures to mitigate deposit formation can be adopted, such as increasing the compression strength of preheated pellets, choosing high-quality raw materials with low alkali metals, improving the combustion of pulverized coal.
\end{abstract}

Keywords: rotary kiln; pulverized coal; pellets; combustion efficiency; deposit formation; liquid phase

\section{Introduction}

As an important component of ironmaking charge, pellets are characterized by their high grade, uniform particle size, better strength and metallurgical performance than natural lump ores and sinters; the advantages in environmental protection and energy conservation are especially obvious [1]. The iron ore pellets produced by grate-kilns can obtain high yield, better adaptability to raw materials, uniform roasting temperature and stable product quality [2]. In addition, the grate-kiln method can use a variety of fuels to provide heat, which is especially beneficial to countries with rich coal resources [3]. These advantages made the method of grate-kiln producing iron ore pellets develop rapidly in the world [4,5]. However, the deposit formed during the pellet roasting process has become a widespread problem, which seriously restricts the further development of this method.

The deposit is a ring-like material adhering to the refractory brick of the rotary kiln lining during the production of iron ore pellets. In the initial formation stage, the deposit has a slight effect on the pellet production. Nevertheless, as the deposit accumulates towards the pellet layer, the cross-sectional area of the high-temperature region in the rotary kiln will decrease, and the transport of air and pellets will be impeded, which affects the roasting effect of pellets [6]. A large area of deposits can even stick to the preheated 
pellets to accelerate the accumulation rate, which will increase the equipment load and reduce productivity [7]. With the rapid decline of pellet production and quality, the rotary kiln must be stopped to deal with deposits on the lining. It should be noted that each period of rotary kiln maintenance to clean the deposits not only affects the pellet output and produces lots of low-strength pellets, but also requires a large amount of fuel for the reheating of the rotary kiln. The more severe problem is that the thickness of refractory bricks keeps thinning with the shedding of deposits on their surface, which leads to the decline of the abrasive resistance and heat resistance of the rotary kiln [8]. Therefore, it is necessary to study the deposit-forming mechanism of coal-fired rotary kilns and the measures to slow down the deposit accumulation.

Up to now, some previous research has reported that the incomplete combustion of pulverized coal injection plays a significant influence on the deposit formation of rotary kiln. The incomplete burnt pulverized coal containing residual carbon and a large amount of coal ash was mixed with preheated pellet powder, which would produce local reducing atmosphere to form low-melting-temperature compounds by residual carbon combustion during the roasting process $[9,10]$. These compounds are usually composed of $\mathrm{Fe}, \mathrm{Ca}, \mathrm{Si}$, $\mathrm{Al}, \mathrm{K}$ and $\mathrm{Na}$, which have melting temperatures below $1673 \mathrm{~K}$ [11] and melt into the liquid phase in the high-temperature region of the rotary kiln $[12,13]$. Due to the better fluidity, the liquid phase is continuously depositing onto the brick surface. Finally, the liquid phase reacts with the corundum in the refractory brick and adheres to its surface to form the initial deposits [14]. In addition, oil-rich countries add petroleum coke into pulverized coal to reduce fuel costs. The fixed carbon content of petroleum coke is usually above $80 \%$, which increases the residual carbon content in the combustion products, and the ash content of petroleum coke is less than $1.2 \%$, which is beneficial to reduce the material basis for the formation of rotary kiln deposits [15]. Because of the relatively high sulfur content, the additive amount of petroleum coke needs to be limited [16].

For the deposit formation, researchers have conducted significant research and made continuous improvement on the grate-kiln production process, which has achieved remarkable results. Based on the previous work carried out by our research group, this paper summarized the formation mechanism and influencing factors of deposit formation in a coal-fired rotary kiln, and put forward the prospect of the development direction to prevent deposit forming.

\section{Formation Mechanism of Deposit in Coal-Fired Rotary Kiln}

\subsection{Description of Grate-Kiln Process and Equipment}

The grate-kiln process includes pelletizing, drying-preheating, roasting and cooling of pellets, which is carried out by pelletizer, grate, rotary kiln and cooler respectively $[17,18]$. These devices are connected in series to form a complete pellet production line. High grade $(>60 \%)$ iron concentrate powder is mixed with a binder, flux, and fly ash to prepare green pellets with the particle size of $8 \sim 16 \mathrm{~mm}$ by the disc pelletizer, and then evenly distributed on the grate machine for subsequent processing [19]. Figure 1 shows the schematic diagram of the grate-kiln process in a pelletizing plant in China [20]. Grates, rotary kilns and ring coolers are all large production equipment, which usually has no standby facility to take its place. Therefore, when these facilities break down and need to be shut down for maintenance, it will result in serious impacts on the pellet production. Thus, the researches on deposit of rotary kilns has great significance to the wide application of the grate-kiln process. 


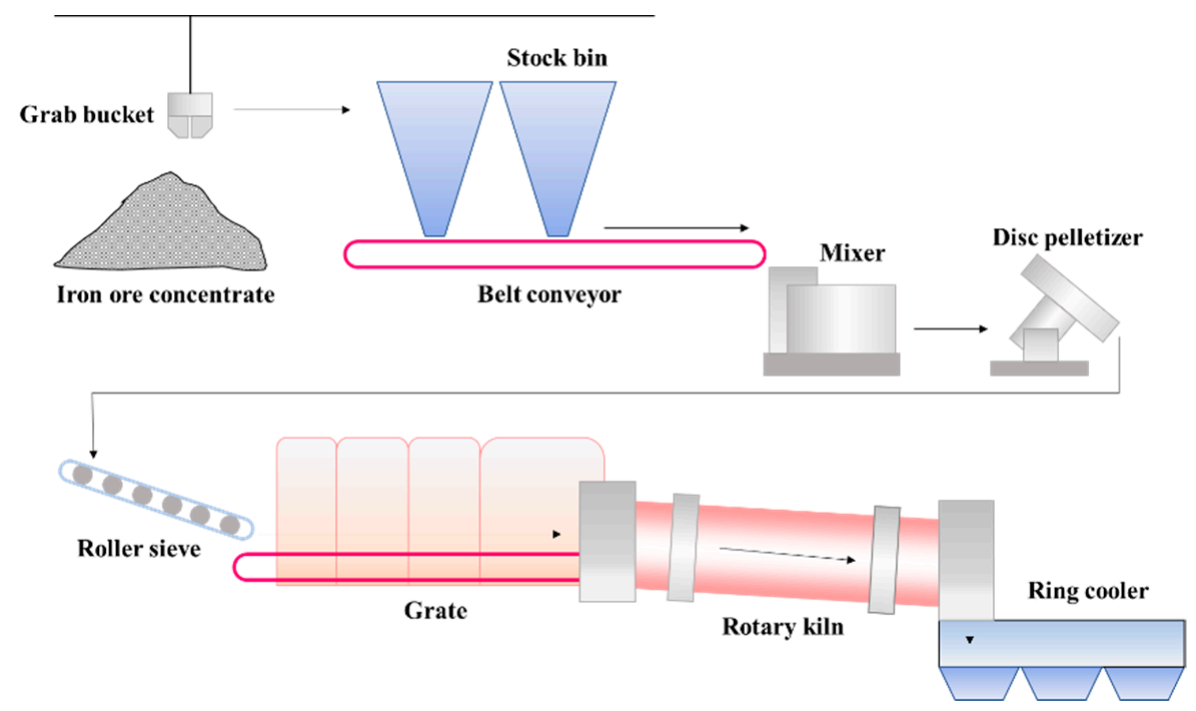

Figure 1. Schematic diagram of the grate-kiln technological process.

\subsection{The Distribution of Deposit in Coal-Fired Rotary Kiln}

The distribution of deposits in a grate and rotary kiln is mainly affected by pulverized coal injection and temperature field [21,22]. As shown in Figure 2, at the heads of the rotary kiln, pulverized coal is sprayed with high-pressure air and burned to provide heat for the drying, oxidation and consolidation of pellets. In addition, the high-temperature exhaust gas from the cooler serves as the secondary air to provide a stable temperature field for the grate and the rotary kiln [23]. Influenced by the flame shape generated by pulverized coal combustion, the temperature in the middle of the rotary kiln is usually higher than that in the head and tail of the kiln [24,25]. Therefore, the deposit-forming phenomenon in the middle of the kiln is more pronounced. In previous experiments, we selected the sediments from different regions of the grate and rotary kiln for chemical element composition analysis, as shown in Table $1[2,26]$. The obtained results indicate that the total iron content from $\mathrm{K} 1$ to $\mathrm{K} 7$ showed a decreasing trend, while the contents of $\mathrm{K}, \mathrm{Na}$ and $\mathrm{Si}$ increased gradually. This study confirmed that the distribution regularity of chemical composition of deposit in the rotary kiln was mainly affected by pulverized coal injection. The residual coal ash produced by pulverized coal combustion is driven by hot air to the kiln tail, which makes the deposit in the K4-K7 region contain more coal ash components, while the chemical composition of the deposit in the $\mathrm{K} 1-\mathrm{K} 3$ region is similar to pellets.

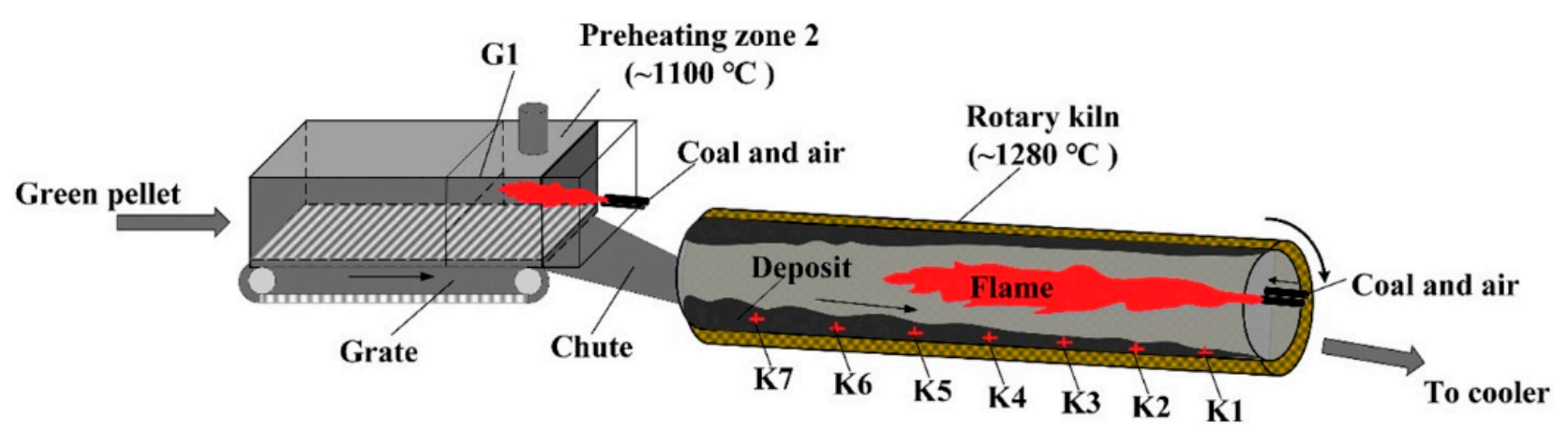

Figure 2. Schematic diagram of the grate-kiln plant [27]. 
Table 1. Chemical compositions of the deposit samples (wt\%) [27].

\begin{tabular}{ccccccccc}
\hline No. & $\mathbf{T F e}$ & $\mathbf{S i O}_{2}$ & $\mathbf{C a O}$ & $\mathbf{A l}_{\mathbf{2}} \mathbf{O}_{\mathbf{3}}$ & $\mathbf{M g O}$ & $\mathbf{K}_{\mathbf{2}} \mathbf{O}$ & $\mathbf{N a}_{\mathbf{2}} \mathbf{O}$ & $\mathbf{S}$ \\
\hline $\mathrm{G} 1$ & 55.78 & 9.12 & 3.03 & 5.07 & 1.26 & 0.29 & 0.25 & 0.0050 \\
$\mathrm{~K} 1$ & 66.04 & 2.51 & 1.74 & 1.53 & 0.81 & 0.043 & 0.058 & 0.0050 \\
$\mathrm{~K} 2$ & 66.40 & 2.66 & 1.95 & 1.30 & 0.88 & 0.042 & 0.070 & 0.0050 \\
$\mathrm{~K} 3$ & 64.22 & 4.05 & 1.91 & 1.91 & 0.93 & 0.062 & 0.095 & 0.0055 \\
$\mathrm{~K} 4$ & 62.98 & 5.19 & 2.45 & 2.46 & 0.85 & 0.088 & 0.120 & 0.0050 \\
$\mathrm{~K} 5$ & 61.93 & 5.91 & 2.41 & 2.25 & 1.37 & 0.089 & 0.160 & 0.0070 \\
$\mathrm{~K} 6$ & 62.11 & 5.72 & 1.91 & 2.36 & 0.79 & 0.110 & 0.640 & 0.0023 \\
$\mathrm{~K} 7$ & 62.60 & 5.72 & 2.02 & 2.11 & 0.90 & 0.082 & 0.19 & 0.0020 \\
\hline
\end{tabular}

\subsection{The Agglomerating Mechanism of Deposit}

The massive deposits discharged by natural cooling during the maintenance of a rotary kiln include two kinds of morphology: loose type and tight type are shown in Figure 3. The loose type is taken from the surface layer of the deposit, while the tight type is from the bottom layer closer to the refractory material of the kiln wall. In Figure 3a, loose type deposits embed lots of preheating pellets. This structure is formed by the preheating pellets that adhere to the liquid phase melted from pellet powder and coal ash at high temperatures. The loose deposits are formed shortly before rotary kiln maintenance, thus the morphology of pellets on the surface is still relatively regular. In contrast, the tight type deposits in Figure $3 \mathrm{~b}$ are formed earlier [28]. The liquid phase continually fills into the pores of the primary deposit, which makes the deposit structure more compact [29]. Furthermore, because of the pressure exerted by the rolling pellet layer, the volume of the primary deposit is continuously compressed and eventually forms a tight structure. The newly formed deposits continue to grow on the primary deposits, thickening layer by layer, further impeding the advance of the rolling pellets layer [30].
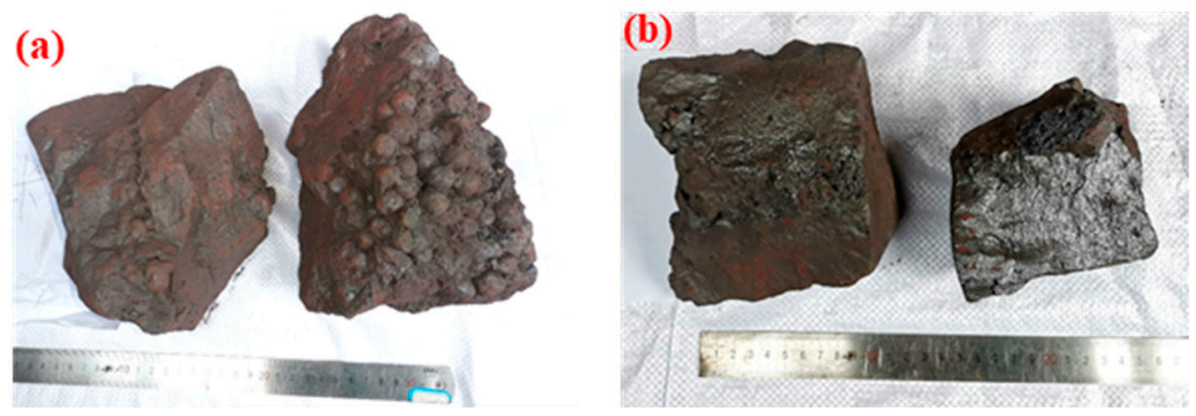

Figure 3. The massive deposit, including (a) loose type deposit; (b) tight type deposit.

\subsection{The Microstructure of Deposit}

Figure 4 shows the microstructure of the rotary kiln deposit of iron ore pellets. The deposits are usually composed of hematite, silicate (hedenbergite and anorthite), spinel [27]. In the process of high-temperature roasting, hematite particles from preheated pellet powder adhere together in the molten silicate binding phase to form the microstructure of deposits in rotary kiln [31]. The binding phase is composed predominantly of $\mathrm{SiO}_{2}$, $\mathrm{CaO}, \mathrm{Al}_{2} \mathrm{O}_{3}, \mathrm{MgO}$ and $\mathrm{Fe}_{2} \mathrm{O}_{3}$. Because of the better fluidity, the silicate melt depends on its own gravity and the rotary kiln centrifugal force to continuously deposit on the kiln lining, which results in the deposit microstructure becoming denser [32]. Meanwhile, the combustion of fixed carbon in the incomplete burned pulverized coal produces a local reducing atmosphere in the pellet powder, which reduces $\mathrm{Fe}^{3+}$ to $\mathrm{Fe}^{2+}$. Then, the $\mathrm{Fe}^{2+}$ reacts with $\mathrm{MgO}$ and $\mathrm{Al}_{2} \mathrm{O}_{3}$ to form spinel [26]. In general, the microstructure formed by the bonding of silicate melt with hematite and spinel has high strength, which makes it difficult to be completely destroyed by the friction and collision from the rolling pellet layer [33]. 

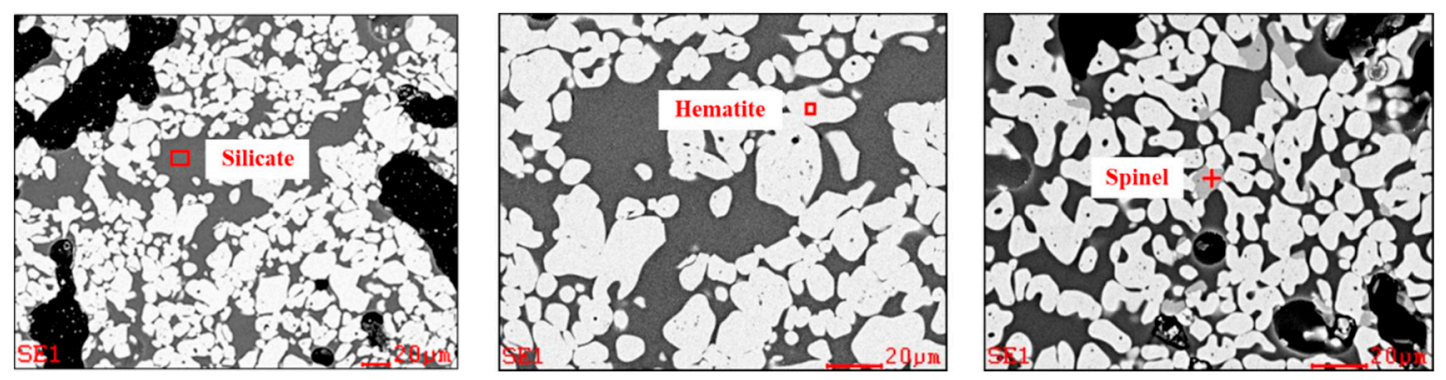

Figure 4. SEM images of the deposit in rotary kiln [26].

\subsection{The Adhesion of Deposit to Refractory Bricks}

The refractory material of the lining in the coal-fired rotary kiln is usually composed of corundum and mullite [34,35]. Previous studies have analyzed the process of deposit adhesion and penetration on refractory bricks [36]. The adhesion of the deposit first occurs at the defects on the refractory brick surface. As shown in Figure 5, due to the thermal impact in the process of high-temperature roasting, the surface temperature of refractory bricks is too high to produce the "separation" phenomenon, which results in cracks [37]. The deposits formed by preheated pellet powder and incomplete burned pulverized coal preferentially accumulate at these defects. The testing of rotary kiln lining refractory bricks used for 14 months reveals a minimal amount of silicate glassy phases around corundum particles on the bricks' surface, which indicates that the penetration of the sedimentary liquid phase is not apparent at this time. After four years of usage, the surface of refractory bricks adheres to a thicker hematite layer. Meanwhile, due to the erosion of the liquid phase, part of the corundum particles are released, migrate to the hematite layer and react with hematite to form a spinel-type solid solution [32]. From Figure 6a, we can clearly observe the adhesion and erosion of deposits to refractory materials. From Figure $6 \mathrm{~b}$, as the service of rotary kiln lining refractory bricks continues, the grain boundary between the hematite layer and the corundum layer becomes indistinguishable. Affected by the infiltration of the molten liquid phase, hematite and corundum particles migrate between deposits and refractories. In addition, when the deposits grow enough to affect the pellet production, it is necessary to frequently stop the operation of the rotary kiln to remove them. In the cooling process of rotary kiln, the volume contraction of the silicate glass phase will generate cracks and fracture surfaces in the deposits. With the kiln rotating, large chunks of deposits fall off the lining to be discharged under the influence of gravity. The erosion effect of the deposits makes them closely connected with the refractory brick. Because of the weak tensile strength, with the shedding of deposits, the surface layer of refractory materials may be separated to shorten their service life [38].
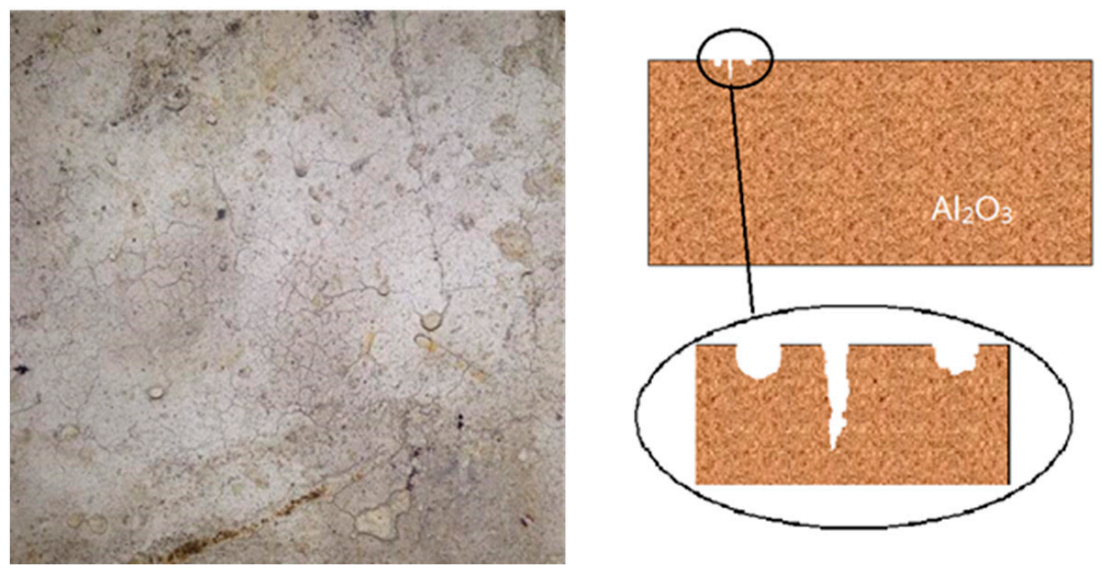

Figure 5. The morphology of crack on refractory brick surface. 

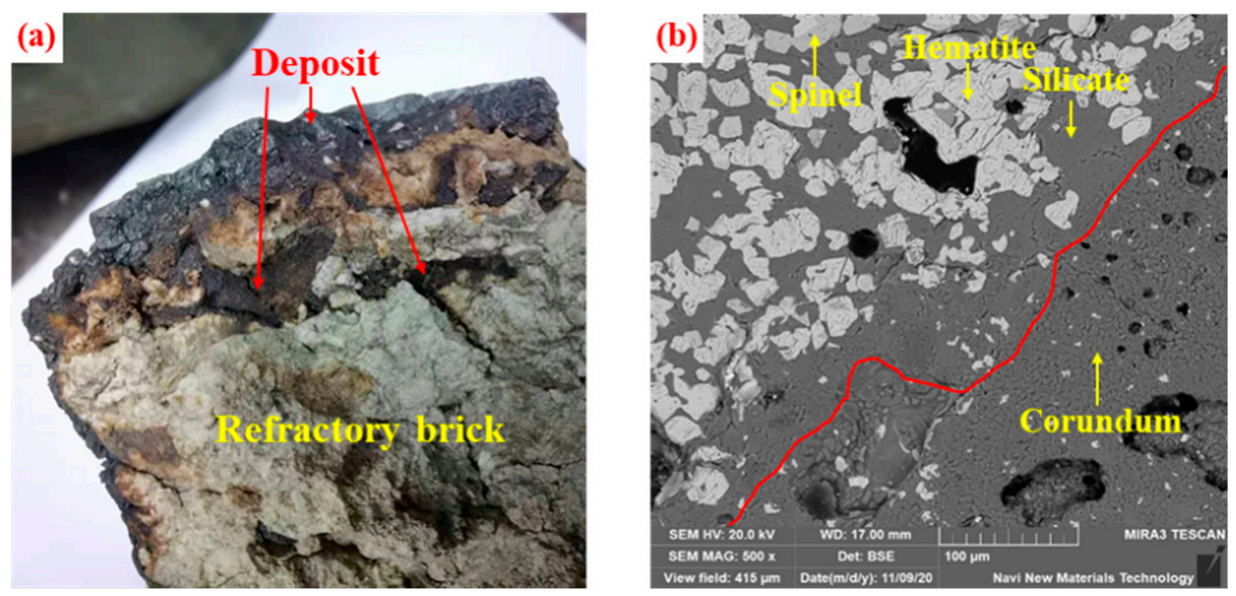

Figure 6. The morphology of ring adhesion to firebrick, including (a) the macroscopic morphology of ring adhesion to firebrick; (b) the micromorphology of ring adhesion to firebrick.

\subsection{The Mechanism of the Deposit Formation}

The pellet production system relies on the combustion of pulverized coal ejected from the coal injection device to provide heat for pellet drying, preheating and roasting. However, the pulverized coal injection usually can not burn completely [39], which causes a small amount of fixed carbon left in the coal ash [40]. As shown in Figure 7, the unburned carbon and coal ash are sprinkled in the pellet layer and mixed with the pulverized pellet powder. This mixed powder enters into the gaps of refractory brick while it is rolling with the pellets. The high temperature in the rotary kiln causes the residual carbon combustion to produce a local reducing atmosphere, which reduces the $\mathrm{Fe}^{3+}$ to $\mathrm{Fe}^{2+}$ [41]. With the increase of $\mathrm{Fe}^{2+}$ content, the melting point of the mixed powder decreases, and the liquid phase gradually erodes the surface of the refractory brick [42]. Meanwhile, the liquid phase adheres to more pulverized pellet powder, coal ash and unburned carbon through its surface tension [8]. In this way, the initial deposits on the surface of refractory brick are formed. As the circulation of the adhesion process continues, the deposits gradually thicken in a "layer by layer" pattern, and eventually form a solid construction.

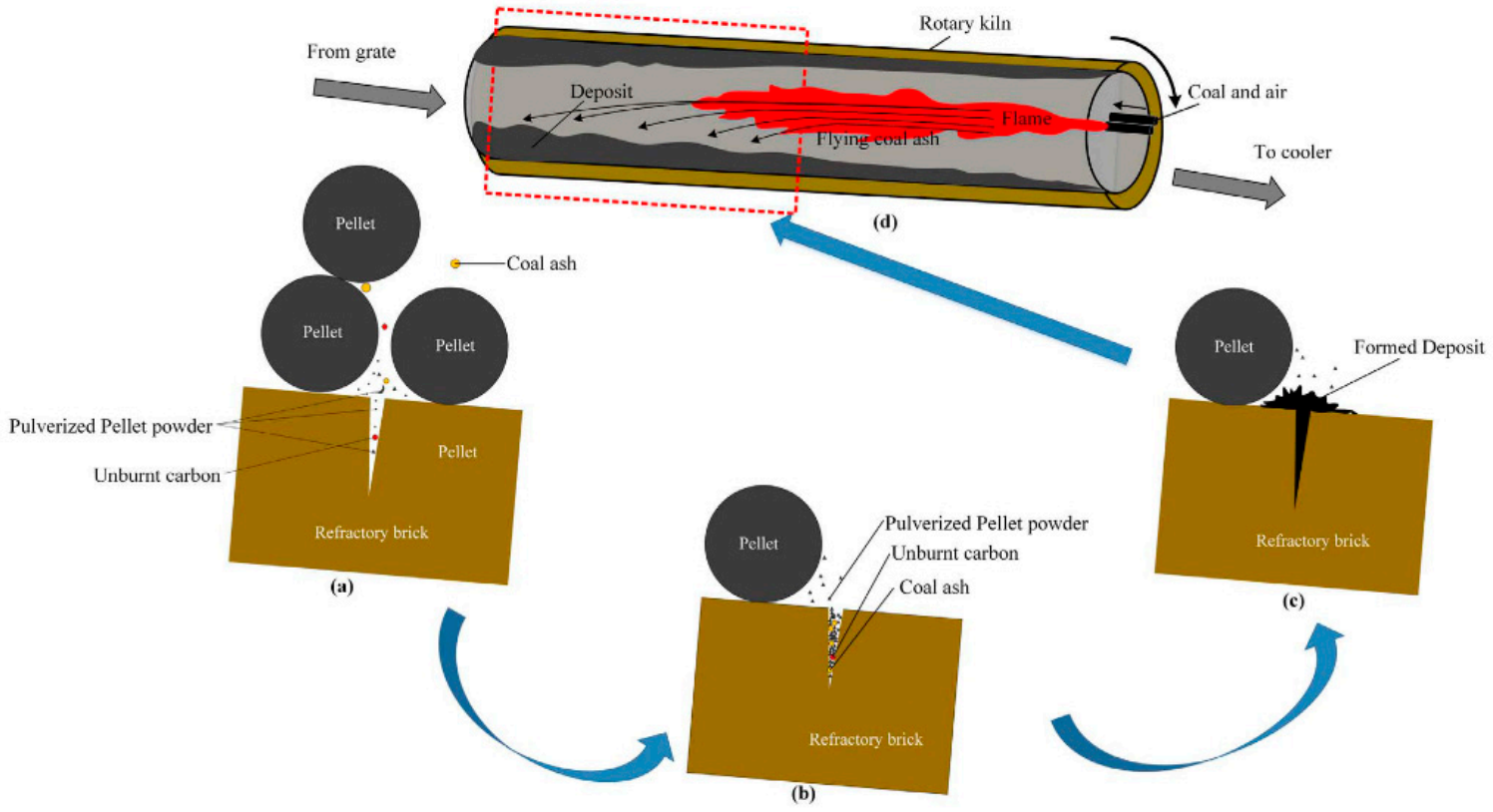

Figure 7. Schematic diagram of the deposit formation process [43]. 


\section{The Factors Affecting Deposit Formation}

\subsection{Effect of Pellet Powder}

The pellet powder is the material base of deposit formation in a rotary kiln, which comes from the following sources. When the moist green pellets enter the drying region of the grate, the higher temperature and the slow air flow speed may cause the water vapor inside the green pellets not to be eliminated in time, which will aggravate the internal stress and make the green pellets break into a large amount of powder [44,45]. Some of the fragmentized powder is returned to the pelletizing system, and the rest is sent to the rotary kiln with the preheated pellets. In addition, due to collision and friction between preheated pellets during the rotating process with the kiln, the powder that is not firmly consolidated on the surface of the pellets will fall into the material layer [46]. The increase of preheated pellet powder in the material layer will lead to more hematite particles adhering to the surface of the deposits [47]. Therefore, in order to slow down the accumulation of hematite particles on the deposit surface, methods of improving the strength and adjusting the moisture content of green pellets, as well as selecting the appropriate drying temperature and pellet layer thickness should be adopted.

\subsection{Effect of Coal Ash}

The coal ash composed of $\mathrm{SiO}_{2}, \mathrm{Al}_{2} \mathrm{O}_{3}$ and $\mathrm{CaO}$ is formed after the pulverized coal injection is fully burned [48]. Due to its lightweight and fine particle size [49,50], the coal ash floats towards the tail of the rotary kiln with the airflow, finally scattering on the rolling pellet layer and the kiln lining [51]. In particular, the $\mathrm{SiO}_{2}, \mathrm{Al}_{2} \mathrm{O}_{3}$ and $\mathrm{CaO}$ in deposits mainly come from coal ash. These elements in coal ash react with $\mathrm{Fe}^{2+}$ reduced by $\mathrm{Fe}^{3+}$ around the fixed carbon to form a silicate binding phase, which is the main substance leading to the formation and accumulation of deposits [52]. At the initial stage of deposit formation, the strength of the microcrystalline bond between hematite particles is weak and easily destroyed. However, the silicate binding phase can adhere to the kiln lining, which makes the initial ring avoid being completely destroyed by the friction and impact of the rolling pellet layer. As the pellet production continues, the pellet powder adheres to the silicate binding phase and recrystallizes to form indestructible structures [53]. Therefore, in order to reduce the amount of $\mathrm{SiO}_{2}, \mathrm{Al}_{2} \mathrm{O}_{3}$ and $\mathrm{CaO}$ brought into the pellet layer, pulverized coal injection with relatively lower ash content should be prioritized [54].

\subsection{Effect of Pulverized Coal Combustion Efficiency}

Figure 8a reveals the combustion process of pulverized coal injection. The pulverized coal is ejected from the coal gun and preheated after exposure to thermal radiation in the rotary kiln. Then, the volatile substances evolve rapidly, and the fixed carbon begins to burn. Due to the influence of atmosphere and particle size, the combustion of the pulverized coal may not completely end before it reaches the pellet layer, which leads to a small amount of residual carbon in the combustion products [55,56]. Previous studies show that the lower the combustion efficiency of pulverized coal injection, the higher the residual carbon content in the combustion products [51]. The residual carbon will continue to burn after entering the pellet layer and causes a local reducing atmosphere. Then, the hematite particles around the residual carbon are reduced to $\mathrm{Fe}_{3} \mathrm{O}_{4}$ and $\mathrm{FeO}$ [31]. These low-valent iron oxides will continue to react with quartz to form lower melting point silicate, which melts into the liquid phase during roasting to promote deposit formation. Figure $8 \mathrm{~b}$ shows the adhesion performance of pulverized coal with $85-100 \%$ combustion efficiency to the refractory brick of the rotary kiln lining. With the decrease of pulverized coal combustion efficiency, the adhesion percentage of deposits on the surface of refractory brick increases. In order to inhibit the deposits' further accumulation, methods that appropriately reduce the particle size of pulverized coal and increase the oxygen density in the rotary kiln should be adopted to improve the combustion efficiency of pulverized coal [43]. 

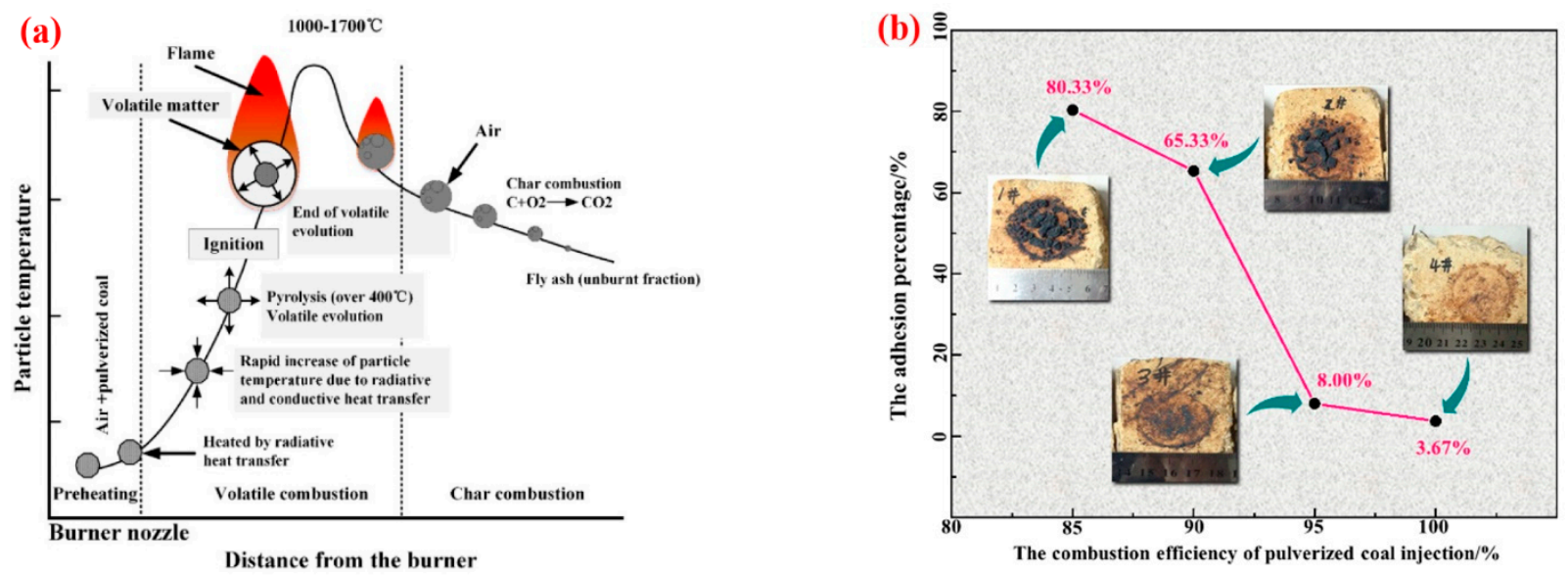

Figure 8. Effect of pulverized coal combustion efficiency, including (a) illustration of combustion phenomena of pulverized coal [26]; (b) the adhesion performance of pulverized coal with $85-100 \%$ combustion efficiency [43].

\subsection{Effect of Roasting Temperature}

In the roasting process, a stable rotary kiln temperature is usually required to ensure smooth production [44]. However, for pelletizing plants with unstable ore sources, the composition of iron concentrate changes frequently, forcing operators to adjust the temperature of the rotary kiln to improve the performance of roasting pellets [57]. Importantly, the melting point of the deposit-forming silicate is close to the roasting temperature range of iron ore pellets. An improper adjustment operation of the rotary kiln temperature may cause further aggravation of the deposit-forming problem. Factsage software provides phase diagram calculation of multi-component systems [58], which can be used to obtain the isothermal cross-section of liquid phase formed by different component contents in the deposit. The isotherm distribution of ternary phase diagrams of $\mathrm{FeO}-\mathrm{CaO}-\mathrm{SiO}_{2}$ and FeO- $\mathrm{Al}_{2} \mathrm{O}_{3}-\mathrm{SiO}_{2}$ are shown in Figure $9 \mathrm{a}$,b, respectively. The phase diagram shows the wide liquid isothermal sections in the temperature range of $1100{ }^{\circ} \mathrm{C}$ to $1600{ }^{\circ} \mathrm{C}$. It is worth noting that as the temperature of the isotherm increase, the proportion of the isotherm section gradually expands. When the rotary kiln temperature rises to the melting point of silicate in the deposit, the liquid phase will form on the deposit surface and continuously adhere to the powder from the pellet layer [33]. The high-temperature roasting can promote the microcrystalline link of hematite and enhance the consolidation strength of the iron ore pellets. Therefore, increasing the roasting temperature is a "double-edged sword", which can improve the pellet performance and aggravate the deposit-forming when the grate-kiln method is used to produce pellets. We can adopt the grate-kiln "Expert System" to select the appropriate roasting temperature intelligently, which can not only ensure the physical properties of oxidized pellets, but also inhibit the growth of deposit formation. This system consists of five parts, respectively, data preprocessing, simulation model, knowledge base, inference engine and global database. The "Expert System" software is programmed and developed by Visual $\mathrm{C}++$, which would realize stable production by controlling the temperature of the pellet roasting in the kiln $[59,60]$.

\subsection{Effect of FeO Content}

After the combustion of pulverized coal injection, the Fe content in the remaining products is usually less than $10 \mathrm{wt} \%$, which could prevent the iron-containing liquid phase from forming in large quantities. However, the incorporation of pellet powder makes the content of Fe increase rapidly, which provides the material basis for deposit formation [31]. The continued combustion of residual carbon results in the reduction of hematite to magnetite $\left(\mathrm{Fe}_{3} \mathrm{O}_{4}\right)$ and wustite $(\mathrm{FeO})[61,62]$. $\mathrm{FeO}$ reacts with $\mathrm{SiO}_{2}$ to form stable low-melting-point compound fayalite $\left(\mathrm{Fe}_{2} \mathrm{SiO}_{4}\right)$ [63]. Due to the fact that the melting point is lower than the pellets roasting temperature, $\mathrm{Fe}_{2} \mathrm{SiO}_{4}$ is considered to be the major 
component further forming the liquid phase in the deposit. In contrast, hematite usually requires the participation of $\mathrm{Ca}^{2+}$ and $\mathrm{Al}^{3+}$ to react with $\mathrm{SiO}_{2}$. Figure 10a,b calculate the isotherm distribution of $\mathrm{SiO}_{2}-\mathrm{CaO}-\mathrm{Al}_{2} \mathrm{O}_{3}-\mathrm{FeO}$ quaternary phase diagram at $1200{ }^{\circ} \mathrm{C}$ and $1300{ }^{\circ} \mathrm{C}$ respectively. With the increase of $\mathrm{FeO}$ content, the area of the isothermal cross section expands sharply. This study confirms the importance of $\mathrm{FeO}$ content for the formation of liquid phase in the initial deposit [10]. In the process of high-temperature roasting, the silicate liquid phase containing $\mathrm{Fe}^{2+}$ will not only continuously corrode the kiln lining refractory brick, but also cause the pellet powder adhering on new deposits. Meanwhile, the solidified silicate glassy phase further improves the strength of the deposits.
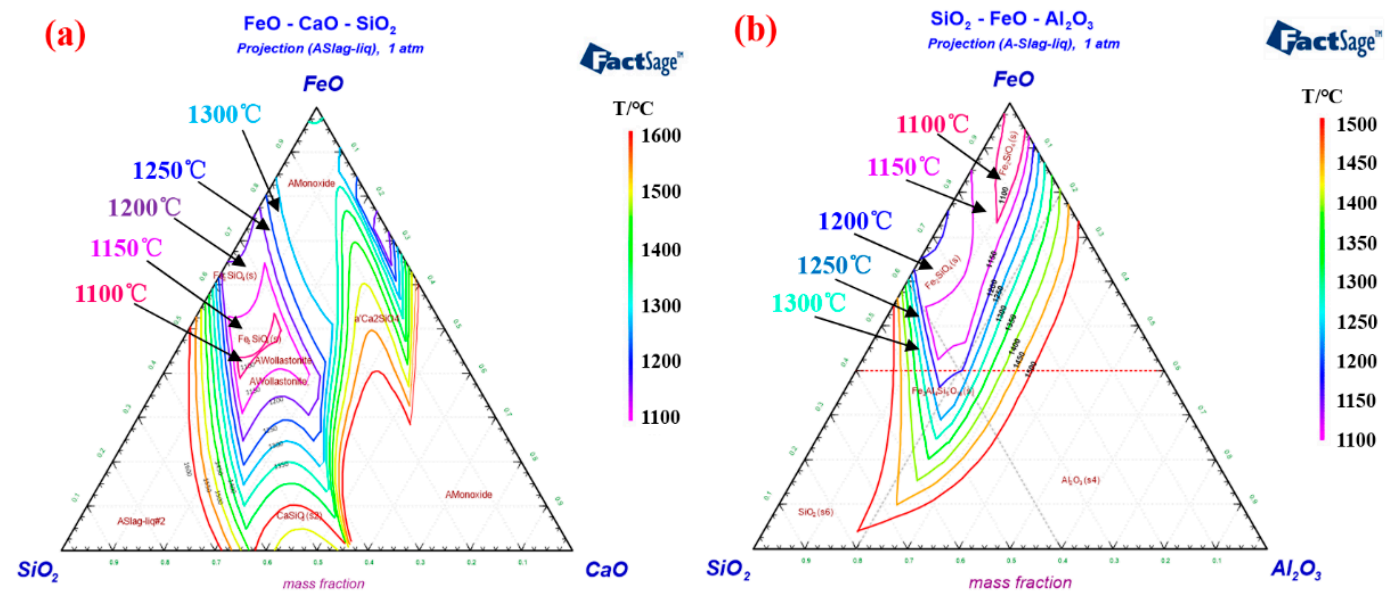

Figure 9. The phase diagram, including (a) phase diagram of $\mathrm{FeO}-\mathrm{CaO}-\mathrm{SiO}_{2} ;$ (b) phase diagram of $\mathrm{FeO}-\mathrm{Al}_{2} \mathrm{O}_{3}-\mathrm{SiO}_{2}$.
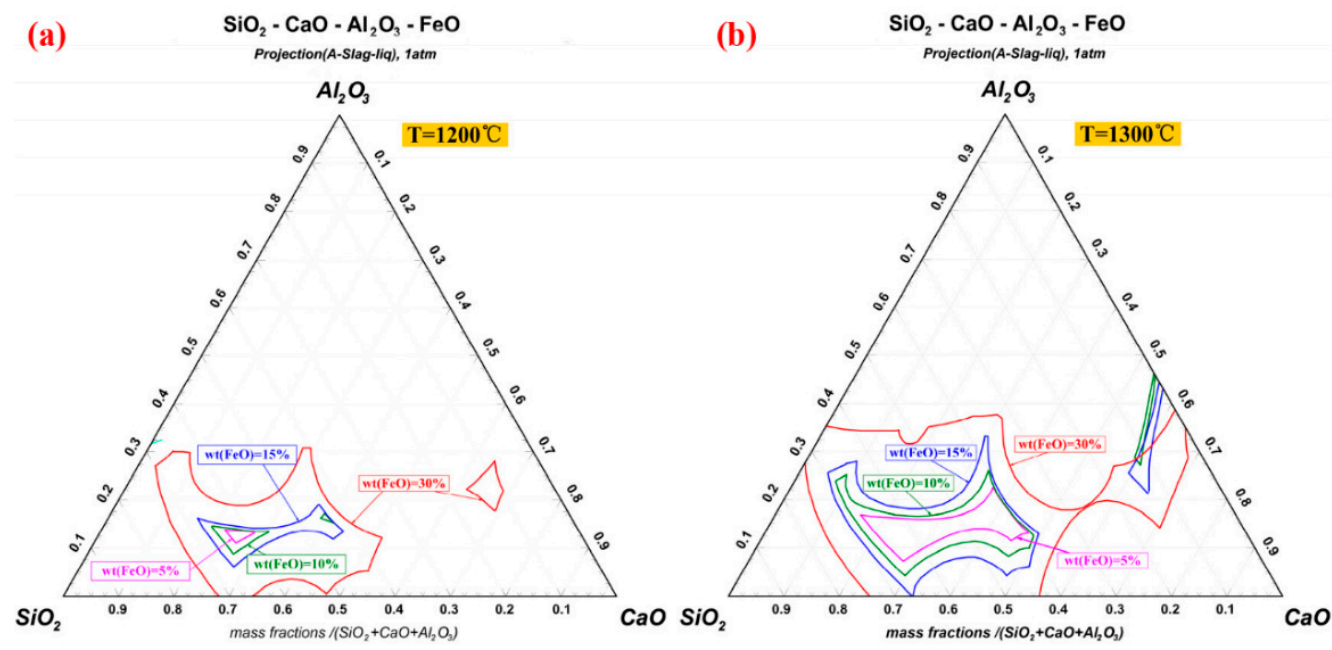

Figure 10. The phase diagram, including (a) phase diagram of $\mathrm{SiO}_{2}-\mathrm{CaO}-\mathrm{Al}_{2} \mathrm{O}_{3}-\mathrm{FeO}\left(1200{ }^{\circ} \mathrm{C}\right)$; (b) phase diagram of $\mathrm{SiO}_{2}-\mathrm{CaO}-\mathrm{Al}_{2} \mathrm{O}_{3}-\mathrm{FeO}\left(1300{ }^{\circ} \mathrm{C}\right)[10]$.

\subsection{Effect of Alkali Metals Content}

Alkali metal elements of the rotary kiln system mainly exist in the pulverized coal and iron concentrate [64], which are brought by coal ash and pellets powder into the deposits [65]. The presence of $\mathrm{Na}$ and $\mathrm{K}$ can be found in the chemical element detection of deposits $[66,67]$. Due to the fact that alkali metals can form low melting point substances with other compounds [68], they have an important influence on deposit formation [69]. During the liquid phase deposition, $\mathrm{Na}^{+}$and $\mathrm{K}^{+}$enter the silicate phase together with $\mathrm{Al}^{3+}$, $\mathrm{Ca}^{2+}, \mathrm{Fe}^{2+}$ and $\mathrm{Fe}^{3+}$. Moreover, alkali metals have a high affinity for $\mathrm{Al}^{3+}[70]$, thus corrode refractory bricks containing corundum and mullite [71]. Figure 11a-c displays the isotherm 
distribution of the $\mathrm{Al}_{2} \mathrm{O}_{3}-\mathrm{CaO}-\mathrm{SiO}_{2}-\mathrm{Na}_{2} \mathrm{O}$ quaternary phase diagram with $0.01 \%, 0.05 \%$ and $0.1 \% \mathrm{Na}_{2} \mathrm{O}$ addition, respectively. As the amount of $\mathrm{Na}_{2} \mathrm{O}$ increases, the isothermal cross-section area in the range of $1000-1400{ }^{\circ} \mathrm{C}$ of the quaternary phase diagram expands noticeably. Although a small amount of $\mathrm{Na}_{2} \mathrm{O}$ was added, the liquid phase formation in the $\mathrm{Al}_{2} \mathrm{O}_{3}-\mathrm{CaO}-\mathrm{SiO}_{2}-\mathrm{Na}_{2} \mathrm{O}$ quaternary system was significantly promoted [44]. According to results researched by Kejiang Li et al. [72], the presence of $\mathrm{Na}_{2} \mathrm{O}$ can significantly reduce the viscosity of the aluminosilicate liquid phase, which is attributed to the fact that $\mathrm{Na}^{+}$ will connect with $\mathrm{O}^{2-}$ to form non-bridged oxygen [73]. The increase of the aluminosilicate liquid phase fluidity will intensify the erosion in the refractory brick and enhance the adhesion property of the deposits [28]. In order to limit the formation of liquid phase, we need to reduce the input of alkali metal elements from coal ash and pellets powder. Thus, it is recommended that high-quality iron concentrate and coal with low alkali metals should be chosen for controlling the deposit formation.

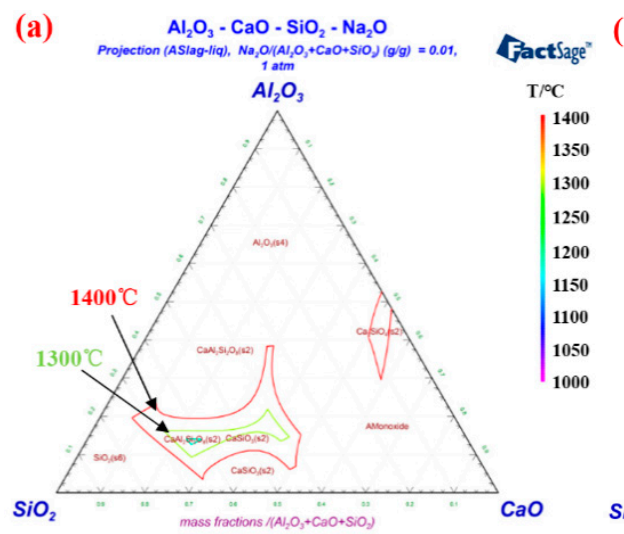

(b)
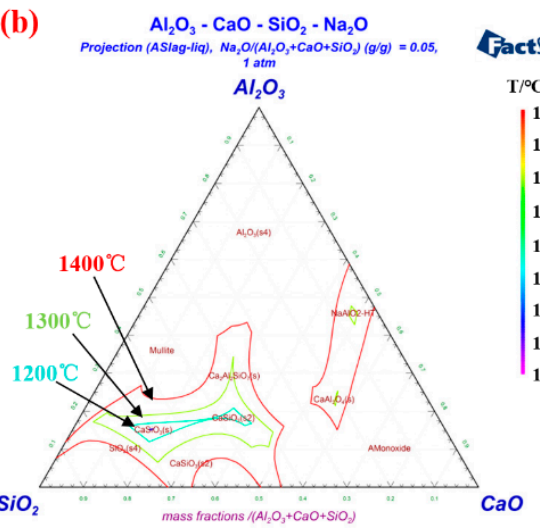

(c)

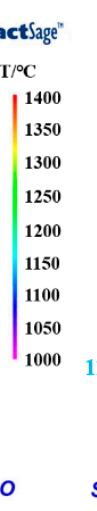

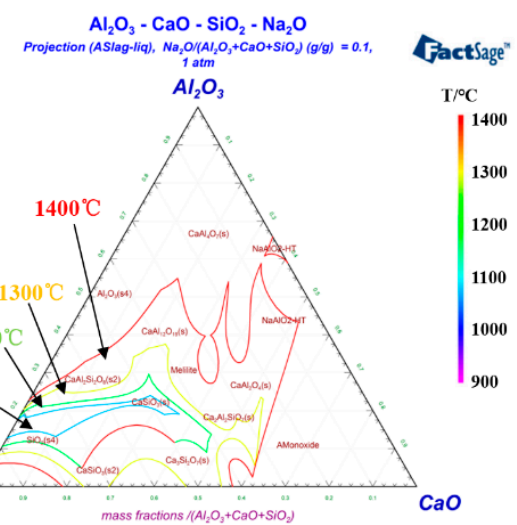

Figure 11. The phase diagram, including (a) phase diagram of $\mathrm{Al}_{2} \mathrm{O}_{3}-\mathrm{CaO}-\mathrm{SiO}_{2}-\mathrm{Na}_{2} \mathrm{O}(0.01 \%)$; (b) phase diagram of $\mathrm{Al}_{2} \mathrm{O}_{3}-\mathrm{CaO}-\mathrm{SiO}_{2}-\mathrm{Na}_{2} \mathrm{O}(0.05 \%)$; (c) phase diagram of $\mathrm{Al}_{2} \mathrm{O}_{3}-\mathrm{CaO}-\mathrm{SiO}_{2}-\mathrm{Na}_{2} \mathrm{O}(0.10 \%)$ [43].

\section{Summary and Outlook}

Deposit formation on the lining of coal-fired rotary kilns is affected by the combined influence between the quality of the green pellets, the composition of coal ash, the combustion efficiency of pulverized coal, roasting temperature, $\mathrm{FeO}$ content and alkali metal input. Therefore, the formation mechanism and influencing factors of deposits are reviewed. The differences in deposit composition between the inlet, middle and outlet of the rotary kiln indicate that the coal ash remaining from the combustion of pulverized coal injection has an essential effect on deposit formation. As the material layer turns over, the pellet powder and the coal ash gather together to form the material base of deposits. Furthermore, the local reducing atmosphere caused by the continued combustion of residual carbon in coal ash increases the $\mathrm{FeO}$ content, resulting in low melting-point compounds formation. Meanwhile, alkali metal elements in coal ash can also promote the formation of the liquid phase to cause serious deposit formation problems. After a long production period, the silicate glassy phase adheres to the surface of the refractory brick and even erodes the corundum grains. The molten silicate liquid phase continues to cause the adhesion of the pellet powder and coal ash from the material layer, resulting in the continuous accumulation of deposits. During high-temperature roasting, the hematite particles from pellet powder further enhance the deposit strength through recrystallization.

The harm of deposit in rotary kilns increases with its accumulation. It is necessary to reduce the material basis for forming deposits and adjusting the production operation to inhibit the deposits growth. In terms of raw material characteristics, iron concentrate with low silicon and alkali metal content should be used for pelletizing. For equipment operation, appropriate drying temperature and air flow rate should be selected to reduce the burst rate of green pellets into powder. In addition, appropriate preheating and roasting thermal parameters could be adopted to improve the strength of pellets and 
prevent the increase of liquid phase caused by excessive local roasting temperature. We need to choose the pulverized coal injection with better combustibility, lower coal ash content, higher ash fusion point, low silicon and alkali metal content in terms of fuel usage. Meanwhile, sufficient combustion-supporting air should be inserted into the rotary kiln to improve the combustion efficiency of pulverized coal. In the future, precise and real-time detection means such as "Grate-kiln Expert System" should be adopted to establish the control module of parameters containing deposit thickness, temperature field and coal injection quantity of the rotary kiln. By adjusting rotary kiln operation in the initial stage of deposit formation, operators can minimize the effect of deposit formation on iron ore pellet production.

Author Contributions: Conceptualization, Y.G. and S.W.; methodology, K.L.; validation, F.C. and F.Z.; formal analysis, K.L. and Z.Y.; writing—original draft preparation, S.W. and K.L.; writingreview and editing, Y.G. and L.Y.; visualization, Y.L. and Y.J.; supervision, Y.G. and S.W. All authors have read and agreed to the published version of the manuscript.

Funding: This research was funded by National Natural Science Foundation of China, grant number 51904348; Shanxi Province Major Science and Technology Projects, grant number 20191101002; Fundamental Research Funds for the Central Universities of Central South University, grant number 2021zzts0294; the Open Sharing Fund for the Large-scale Instruments and Equipments of Central South University, grant number 2021-28.

Data Availability Statement: Data sharing is not applicable to this article.

Acknowledgments: The authors would like to acknowledge the financial supports from the National Natural Science Foundation of China (51904348), the Major Science and Technology Special Project of Shanxi Province (20191101002), Fundamental Research Funds for the Central Universities of Central South University (2021zzts0294) and the Open Sharing Fund for the Large-scale Instruments and Equipments of Central South University (2021-28).

Conflicts of Interest: The authors declare no conflict of interest.

\section{References}

1. Kalra, G.D. Iron ore pellets as a solution to steel-Making raw materials at the crossroad and dominant constituent of basket of iron ores available for export in the future. Miner. Econ. 2014, 26, 127-141. [CrossRef]

2. Fan, X.H.; Jun, L.I.; Chen, X.L.; Wang, Y.; Gan, M. Temperature Field Simulation Model for Rotary Kiln of Iron Ore Oxidized Pellet. J. Iron Steel Res. Int. 2013, 20, 16-19. [CrossRef]

3. Osintsev, K.V.; Prikhodko, I.S. On the issue of mathematical modeling of rotary kiln operation in order to reduce fuel consumption. In Proceedings of the International Conference on Mechanical Engineering, Automation and Control Systems 2018, Beijing, China, 26-28 December 2018; Zykova, A., Martyushev, N., Eds.; Iop Publishing Ltd.: Bristol, UK, 2019; Volume 560.

4. Forsmo, S.P.E.; Forsmo, S.E.; Samskog, P.O.; Björkman, B.M.T. Mechanisms in oxidation and sintering of magnetite iron ore green pellets. Powder Technol. 2008, 183, 247-259. [CrossRef]

5. Uenaka, T.; Isako, H.; Tokutake, K.; Aketa, K. Coal firing in pelletizing plant developed by kobe steel. Ironmak. Steelmak. 1983, 10, 234-239.

6. Si, J.F.; Jia, Y.Z.; Liu, J.T.; Liang, D.L.; Hou, J.J. Structure of rings and ring-forming mechanism of rotary pelletizing kiln. Kang T'ieh/Iron Steel 2014, 49, 17-21, 27.

7. Chatterjee, A.; Mukhopadhyay, P.K. Flow of materials in rotary kilns used for sponge iron manufacture: Part III. Effect of ring formation within the kiln. Metall. Trans. B 1983, 14, 393-399. [CrossRef]

8. Jiang, T.; He, G.Q.; Gan, M.; Li, G.H.; Fan, X.H.; Yuan, L.S. Forming mechanism of rings in rotary-kiln for oxidized pellet. In Proceedings of the 5th International Congress on the Science and Technology of Ironmaking, ICSTI 2009, Shanghai, China, 20-22 October 2009; pp. 292-297.

9. Cabielles, M.; Montes-Moran, M.A.; Garcia, A.B. Structural Study of Graphite Materials Prepared by HTT of Unburned Carbon Concentrates from Coal Combustion Fly Ashes. Energy Fuels 2008, 22, 1239-1243. [CrossRef]

10. Wang, S.; Guo, Y.; Chen, F.; He, Y.; Jiang, T.; Zheng, F. Combustion Reaction of Pulverized Coal on the Deposit Formation in the Kiln for Iron Ore Pellet Production. Energy Fuels 2016, 30, 6123-6131. [CrossRef]

11. Thibodeau, E.; Gheribi, A.E.; Jung, I.H. A Structural Molar Volume Model for Oxide Melts Part III: Fe Oxide-Containing Melts. Metall. Mater. Trans. B Process. Metall. Mater. Process. Sci. 2016, 47, 1187-1202. [CrossRef]

12. Stjernberg, J.; Jonsson, C.Y.C.; Wiinikka, H.; Lindblom, B.; Boström, D.; Öhman, M. Deposit Formation in a Grate-Kiln Plant for Iron-Ore Pellet Production. Part 2: Characterization of Deposits. Energy Fuels 2013, 27, 6171-6184. [CrossRef] 
13. Jonsson, C.Y.C.; Stjernberg, J.; Wiinikka, H.; Lindblom, B.; Boström, D.; Öhman, M. Deposit Formation in a Grate-Kiln Plant for Iron-Ore Pellet Production. Part 1: Characterization of Process Gas Particles. Energy Fuels 2013, 27, 6159-6170. [CrossRef]

14. Min, X.; Yang, Y.; Li, Q.; Xu, B.; Jiang, T.; Liu, X.; Zhang, Y. Comparison of the Ringing Characteristics Between Acid and Alkaline Iron Ore Pellets Powder in Kiln. In 8th International Symposium on High-Temperature Metallurgical Processing; Springer: Cham, Switzerland, 2017; pp. 651-659.

15. Buzunov, V.Y.; Tayanchin, A.S.; Cherskikh, I.V.; Polovnikov, V.M. Quality of Russian Petroleum Cokes for Aluminum Production. In TMS Light Metals; Bearne, G., Ed.; Minerals, Metals and Materials Society: Pittsburgh, PA, USA, 2009 ; pp. $927-931$.

16. Buzunov, V.; Mann, V.; Khramenko, S.; Johnson, J. Influence of Calcination Temperature and Sulfur Level on Coke Properties. In Light Metals 2017; Ratvik, A.P., Ed.; Springer: Cham, Switezerland, 2017; pp. 1151-1156. [CrossRef]

17. Niiniskorpi, V. Iss. Grate-Kiln-Cooler. Where to oxidize and why? In Proceedings of the 61st Ironmaking Conference Proceedings, Nashville, TN, USA, 10-13 March 2002; Iron \& Steel Society: Warrendale, OR, USA, 2002; Volume 61, pp. 533-545.

18. Han, J.X.; IEEE. The Research on the Automatic Control System of Pellet Production of Grat, Rotary Kiln and Annular Cooler. In Proceedings of the 2012 24th Chinese Control and Decision Conference, Taiyuan, China, 23-25 May 2012; IEEE: New York, NY, USA, 2012; pp. 4184-4185.

19. Stjernberg, J.; Isaksson, O.; Ion, J.C. The grate-Kiln induration machine: History, advantages, and drawbacks, and outline for the future. J. S. Afr. Inst. Min. Metall. 2015, 115, 137-144. [CrossRef]

20. Chen, T.J.; Liang, L.S.; Tang, S.M.; Luo, Y.H.; Zhao, Y.L.; Song, S.X. A Case Study on Large-scale Grate-kiln Production of Fluxed Iron Oxide Pellets: Zhanjiang Pelletizing Plant of BaoSteel. Miner. Process. Extr. Metall. Rev. 2019, 40, 123-128. [CrossRef]

21. Hower, J.C.; Groppo, J.G.; Graham, U.M.; Ward, C.R.; Kostova, I.J.; Maroto-Valer, M.M.; Dai, S.F. Coal-derived unburned carbons in fly ash: A review. Int. J. Coal Geol. 2017, 179, 11-27. [CrossRef]

22. Akiyama, K.; Pak, H.; Takubo, Y.; Tada, T.; Ueki, Y.; Yoshiie, R.; Naruse, I. Ash deposition behavior of upgraded brown coal in pulverized coal combustion boiler. Fuel Process. Technol. 2011, 92, 1355-1361. [CrossRef]

23. Song, X.Y.; Fan, Q. The Analysis of Rotary Kiln Thermal Characteristics Based on ANSYS and FLUENT. In Research in Materials and Manufacturing Technologies, Pts 1-3; Kim, Y.H., Yarlagadda, P., Eds.; Trans Tech Publications Ltd.: Durnten-Zurich, Switzerland, 2014; Volume 834, pp. 1523-1528.

24. Li, G.F.; Liu, Z.; Jiang, G.Z.; Liu, H.H.; Xiong, H.G. Numerical simulation of the influence factors for rotary kiln in temperature field and stress field and the structure optimization. Adv. Mech. Eng. 2015, 7, 15. [CrossRef]

25. Umadevi, T.; Lobo, N.F.; Desai, S.; Mahapatra, P.C.; Sah, R.; Prabhu, M. Optimization of Firing Temperature for Hematite Pellets. ISIJ Int. 2013, 53, 1673-1682. [CrossRef]

26. Guo, Y.-F.; Wang, S.; He, Y.; Jiang, T.; Chen, F.; Zheng, F.-Q. Deposit formation mechanisms in a pulverized coal fired grate for hematite pellet production. Fuel Process. Technol. 2017, 161, 33-40. [CrossRef]

27. Wang, S.; Guo, Y.F.; Fan, J.J.; Jiang, T.; Chen, F.; Zheng, F.Q.; Yang, L.Z. Deposits in a coal fired grate-kiln plant for hematite pellet production: Characterization and primary formation mechanisms. Powder Technol. 2018, 333, 122-137. [CrossRef]

28. Wang, Y.Z.; Zhang, J.L.; Liu, Z.J. Rings growth behavior within a pre-reduction rotary kiln: The layered structure and formation mechanism. Powder Technol. 2019, 356, 73-82. [CrossRef]

29. Van Dyk, J.C.; Benson, S.A.; Laumb, M.L.; Waanders, B. Coal and coal ash characteristics to understand mineral transformations and slag formation. Fuel 2009, 88, 1057-1063. [CrossRef]

30. Fu, X.H.; Chen, Z.Z.; Xu, X.Y.; He, L.H.; Song, Y.F. Deposits in Gas-Fired Rotary Kiln for Limonite Magnetization-Reduction Roasting: Characteristics and Formation Mechanism. Metals 2019, 9, 764. [CrossRef]

31. Zhang, Z.X.; Wu, X.J.; Zhou, T.; Chen, Y.S.; Hou, N.P.; Piao, G.L.; Kobayashi, N.; Itaya, Y.; Mori, S. The effect of iron-bearing mineral melting behavior on ash deposition during coal combustion. Proc. Combust. Inst. 2011, 33, 2853-2861. [CrossRef]

32. Stjernberg, J.; Ion, J.C.; Antti, M.L.; Nordin, L.O.; Lindblom, B.; Oden, M. Extended studies of degradation mechanisms in the refractory lining of a rotary kiln for iron ore pellet production. J. Eur. Ceram. Soc. 2012, 32, 1519-1528. [CrossRef]

33. Zhong, Q.; Yang, Y.; Jiang, T.; Li, Q.; Xu, B. Effect of coal ash on ring behavior of iron-ore pellet powder in kiln. Powder Technol. 2018, 323, 195-202. [CrossRef]

34. Xu, G.T.; Li, W.; Chen, X.D.; Zhao, R.K.; Shu, F.H.; Zhang, H.L. Study on ring-forming reasons and refractories used for large-scale gratekiln. Res. Iron Steel 2009, 37, 34-39.

35. Stjernberg, J.; Nordin, L.O.; Ion, J.C. Evaluation of refractory castables and coatings used in pre-heat zone of grate-kiln for iron ore pellet production. Ironmak. Steelmak. 2015, 42, 274-281. [CrossRef]

36. Nie, J.H.; Zhang, Z.Y.; Qiao, W.; Sun, J.Y.; Chen, J.F.; Zhou, Q.; Linag, Y.H. Characteristics of the pellet rotary kiln ring. J. Wuhan Univ. Sci. Technol. 2010, 33, 527-531.

37. Mullinger, P.; Jenkins, B. Industrial and Process Furnaces: Principles, Design and Operation, 2th ed.; Butterworth-Heinemann: Oxford, UK, 2013.

38. Tsweleng, D. Low-cement chrome-oxide-free castable for use in ironmaking rotary kilns. J. S. Afr. Inst. Min. Metall. 2013, 113, 651-658.

39. Bilen, M.; Kizgut, S.; Akkaya, B. Prediction of unburned carbon in bottom ash in terms of moisture content and sieve analysis of coal. Fuel Process. Technol. 2015, 138, 236-242. [CrossRef]

40. Murphy, J.J.; Shaddix, C.R. Combustion kinetics of coal chars in oxygen-enriched environments. Combust. Flame 2006, 144, 710-729. [CrossRef] 
41. McLennan, A.R.; Bryant, G.W.; Stanmore, B.R.; Wall, T.F. Ash formation mechanisms during of combustion in reducing conditions. Energy Fuels 2000, 14, 150-159. [CrossRef]

42. Zhong, R.; Yi, L.; Huang, Z.; Shen, X.; Jiang, T. Sticking mechanism of low grade iron ore-coal composite in rotary kiln reduction. Powder Technol. 2018, 339, 625-632. [CrossRef]

43. Wang, S.; Guo, Y.F.; Fan, J.J.; He, Y.; Jiang, T.; Chen, F.; Zheng, F.Q.; Yang, L.Z. Initial stage of deposit formation process in a coal fired grate-rotary kiln for iron ore pellet production. Fuel Process. Technol. 2018, 175, 54-63. [CrossRef]

44. Kim, H.; Kim, W.H.; Park, J.H.; Min, D.J. A Study on the Effect of Na2O on the Viscosity for Ironmaking Slags. Steel Res. Int. 2010, 81, 17-24. [CrossRef]

45. Feng, J.-X.; Xie, Z.-Y.; Chen, Y.-M. Temperature Distribution of Iron Ore Pellet Bed in Grate. J. Iron Steel Res. Int. $2012,19,7-11$. [CrossRef]

46. Sefidari, H.; Wiinikka, H.; Lindhlom, B.; Nordin, L.O.; Wu, G.; Yazhenskikh, E.; Muller, M.; Ma, C.; Ohman, M. Comparison of high-rank coals with respect to slagging/deposition tendency at the transfer-chute of iron-ore pelletizing grate-kiln plants: A pilot-scale experimental study accompanied by thermochemical equilibrium modeling and viscosity estimations. Fuel Process. Technol. 2019, 193, 244-262. [CrossRef]

47. Liu, X.; Yang, Y.; Zhang, Y.; Li, Q.; Xu, B.; Jiang, T. Cohering Behavior of Iron Ore Pellet Powder in Kiln by a Novel Natural Stacking Method. In 8th International Symposium on High-Temperature Metallurgical Processing; Springer: Cham, Switzerland, 2017; pp. 251-259.

48. Huffman, G.P.; Huggins, F.E.; Shah, N.; Shah, A. Behavior of basic elements during coal combustion. Prog. Energy Combust. Sci. 1990, 16, 243-251. [CrossRef]

49. Buhre, B.J.P.; Hinkley, J.T.; Gupta, R.P.; Nelson, P.F.; Wall, T.F. Fine ash formation during combustion of pulverised coal-coal property impacts. Fuel 2006, 85, 185-193. [CrossRef]

50. Buhre, B.J.P.; Hinkley, J.T.; Gupta, R.P.; Wall, T.F.; Nelson, P.F. Submicron ash formation from coal combustion. Fuel 2005, 84, 1206-1214. [CrossRef]

51. Bandyopadhyay, R.; Gupta, S.; Bo, L.; Jonsson, S.; French, D.; Sahajwalla, V. Assessment of ash deposition tendency in a rotary kiln using Thermo-mechanical analysis and Experimental Combustion Furnace. Fuel 2014, 135, 301-307. [CrossRef]

52. Karamanov, A.; Pisciella, P.; Cantalini, C.; Pelino, M. Influence of $\mathrm{Fe}^{3+} / \mathrm{Fe}^{2+}$ ratio on the crystallization of iron-rich glasses made with industrial wastes. J. Am. Ceram. Soc. 2000, 83, 3153-3157. [CrossRef]

53. Sefidari, H.; Lindblom, B.; Wiinikka, H.; Nordin, L.O.; Mouzon, J.; Bhuiyan, I.U.; Ohman, M. The effect of disintegrated iron-ore pellet dust on deposit formation in a pilot-scale pulverized coal combustion furnace. Part I: Characterization of process gas particles and deposits. Fuel Process. Technol. 2018, 177, 283-298. [CrossRef]

54. Qi, L.W.; Wang, B.; Ma, W.; Yang, Y.B.; Li, S. Study on influences of firing coal quality on ringing of rotary kiln. Sinter. Pelletizing 2016, 41, 28-32.

55. Bilen, M.; Kizgut, S. Modeling of unburned carbon in fly ash and importance of size parameters. Fuel Process. Technol. 2016, 143, 7-17. [CrossRef]

56. Hurt, R.; Sun, J.-K.; Lunden, M. A Kinetic Model of Carbon Burnout in Pulverized Coal Combustion. Combust. Flame 1998, 113, 181-197. [CrossRef]

57. Fan, X.H.; Yang, G.M.; Chen, X.L.; Lu, G.; Huang, X.X.; Xi, L. Predictive models and operation guidance system for iron ore pellet induration in traveling grate-rotary kiln process. Comput. Chem. Eng. 2015, 79, 80-90. [CrossRef]

58. Bale, C.; Chartrand, P.; Degterov, S.A.; Eriksson, G.; Hack, K.; Ben Mahfoud, R.; Melancon, J.; Pelton, A.D.; Petersen, S. FactSage thermochemical software and databases. Calphad-Comput. Coupling Ph. Diagr. Thermochem. 2002, 26, 189-228. [CrossRef]

59. Fan, X.H.; Wang, Y.; Chen, X.L. Mathematical models and expert system for grate-kiln process of iron ore oxide pellet production. Part II: Rotary kiln process control. J. Cent. South. Univ. 2012, 19, 1724-1727. [CrossRef]

60. Wang, Y.; Fan, X.H.; Chen, X.L. Expert System for Control Guidance of Grate-Kiln Pellet Production. ISIJ Int. 2013, 53, 399-402. [CrossRef]

61. Srinivasan, N.S.; Lahiri, A.K. Studies on the reduction of hematite by carbon. Metall. Trans. B 1977, 8, 175-178. [CrossRef]

62. Huffman, G.P.; Huggins, F.E.; Dunmyre, G.R. Investigation of the high-temperature behaviour of coal ash in reducing and oxidizing atmospheres. Fuel 1981, 60, 585-597. [CrossRef]

63. Punjak, W.A.; Shadman, F. Aluminosilicate sorbents for control of alkali vapors during coal combustion and gasification. Energy Fuels 1988, 2, 1679-1689. [CrossRef]

64. Gornostayev, S.S.; Heikkinen, E.P.; Heino, J.J.; Huttunen, S.M.M.; Fabritius, T.M.J. Behavior of Alkali-Bearing Minerals in Coking and Blast Furnace Processes. Steel Res. Int. 2016, 87, 1144-1153. [CrossRef]

65. Wall, T.F. Mineral matter transformations and ash deposition in pulverised coal combustion. Symp. Combust. 1992, 24, 1119-1126. [CrossRef]

66. Luo, G.P.; Nie, X.L.; Wu, S.L.; Wang, Y.B.; Liu, J.T.; Zhou, S.G. Influence of F, K, Na on the ring formation properties of oxidized pellet rotary kiln. Sinter. Pelletizing 2013, 3, 29-32.

67. Sefidari, H.; Ma, C.; Fredriksson, C.; Lindblom, B.; Wiinikka, H.; Nordin, L.O.; Wu, G.; Yazhenskikh, E.; Muller, M.; Ohman, M. The effect of co-firing coal and woody biomass upon the slagging/deposition tendency in iron-ore pelletizing grate-kiln plants. Fuel Process. Technol. 2020, 199. [CrossRef] 
68. Li, K.J.; Zhang, J.L.; Barati, M.; Khanna, R.; Liu, Z.J.; Zhong, J.B.; Ning, X.J.; Ren, S.; Yang, T.J.; Sahajwalla, V. Influence of alkaline $(\mathrm{Na}, \mathrm{K})$ vapors on carbon and mineral behavior in blast furnace cokes. Fuel 2015, 145, 202-213. [CrossRef]

69. Stjernberg, J.; Antti, M.L.; Nordin, L.O.; Oden, M. Degradation of Refractory Bricks Used as Thermal Insulation in Rotary Kilns for Iron Ore Pellet Production. Int. J. Appl. Ceram. Technol. 2009, 6, 717-726. [CrossRef]

70. Gornostayev, S.S.; Tanskanen, P.A.; Heikkinen, E.P.; Kerkkonen, O.; Harkki, J.J. An example of alkalization of SiO2 in a blast furnace coke. Energy Fuels 2007, 21, 2637-2641. [CrossRef]

71. Stjernberg, J.; Olivas-Ogaz, M.A.; Antti, M.L.; Ion, J.C.; Lindblom, B. Laboratory scale study of the degradation of mullite/corundum refractories by reaction with alkali-doped deposit materials. Ceram. Int. 2013, 39, 791-800. [CrossRef]

72. Li, K.J.; Khanna, R.; Bouhadja, M.; Zhang, J.L.; Liu, Z.J.; Su, B.X.; Yang, T.J.; Sahajwall, V.; Singh, C.V.; Barati, M. A molecular dynamic simulation on the factors influencing the fluidity of molten coke ash during alkalization with $\mathrm{K}(2) 0$ and $\mathrm{Na}(2) 0$. Chem. Eng. J. 2017, 313, 1184-1193. [CrossRef]

73. Cormier, L.; Neuville, D.R. Ca and Na environments in Na2O-CaO-Al2O3-SiO2 glasses: Influence of cation mixing and cationnetwork interactions. Chem. Geol. 2004, 213, 103-113. [CrossRef] 